\title{
High frequency of conjugation in Lactobacillus mediated by an aggregation-promoting factor
}

\author{
Roberto Reniero, Piersandro Cocconcelli, Vittorio Bottazzi and Lorenzo Morelli*
}

Istituto di Microbiologia, Facolta' di Agraria, UCSC, via Emilia Parmense 84, 29100 Piacenza, Italy

(Received 23 August 1991; revised 28 November 1991; accepted 9 December 1991)

\begin{abstract}
Lactobacillus plantarum strain 4B2, which exhibits a strong autoaggregating phenotype, receives the broad-hostrange plasmid pAM $\beta 1$ with conjugation efficiencies as high as $10^{-2}$ transconjugants per donor using solid matings; broth matings also occur, but at low transfer frequencies. Filter-sterilized spent supernatant of this strain contains a $32 \mathrm{kDa}$ protein that promotes aggregation, and consequently a high frequency of conjugation, in lactic acid bacteria containing $\alpha$-1,2-glucose-substituted lipoteichoic or teichoic acids. It appears, therefore, that the substituted lipoteichoic or teichoic acids act as receptors for the aggregation-promoting protein.
\end{abstract}

\section{Introduction}

Since the earliest report of conjugal transfer of a drug resistance plasmid into Lactobacillus casei (Gibson et al., 1979), there have been several further reports of plasmid transfer mediated by bacterial mating in lactobacilli. Most of the reports deal with the introduction of pAM $\beta 1$, a broad-host-range conjugative plasmid conferring macrolide resistance (Clewell et al., 1974), into lactobacilli using as donors Enterococcus faecalis or Lactococcus lactis subsp. lactis (Fitzgerald \& Gasson, 1988). Successful conjugal transfer of this plasmid into $L b$. casei (Gibson $e t$ al., 1979), Lb. reuteri (Vescovo et al., 1983; Tannock, 1987), Lb. acidophilus (Vescovo et al., 1983; Luchansky et al., 1989), Lb. plantarum (West \& Warner, 1985; Shrago et al., 1986) and Lactobacillus sp. (Romero \& McKay, 1985) has also been described using agar or filter mating. Some difficulties in using lactobacilli as pAM $\beta 1$ donors have been reported (Gibson et al., 1979; West \& Warner, 1985 ), and deleted forms of pAM $\beta 1$, which were not able to promote their own transfer, were found in $L b$. case $i$ transconjugants (Iwata, 1989). Other workers, however, have shown that lactobacilli can act as donors in interand intrageneric matings on solid media (Cocconcelli et al., 1985; Tannock, 1987; Luchansky et al., 1989), and in the intestinal tract of gnotoxenic mice (Morelli et al., 1988).

\footnotetext{
* Author for correspondence. Tel. 0523 68275; fax 052365205 .
}

Abbreviations: APF, aggregation-promoting factor; EPE, electroendosmosis preparative electrophoresis; LTA, lipoteichoic acid; TA, teichoic acid.
Plasmid conjugation in Lactobacillus is a low-efficiency process: reported frequencies using agar or filter matings generally range from $10^{-7}$ to $10^{-5}$ transconjugants per donor or recipient. A notable exception is $L b$. acidophilus strain $\mathrm{ADH}$, which acts as a $\mathrm{pAM} \beta 1$ recipient at a frequency of $10^{-4}-10^{-2}$ (Luchansky et al., 1989). It was also reported, however, that it was not possible to use ADH transconjugants as donors in a second round of matings. Attempts to achieve conjugal transfer in broth were always unsuccessful, a phenomenon typical of the majority of Gram-positive organisms, which mate only on solid surfaces. Two exceptions to this general rule are known: $E$. faecalis (for reviews see Clewell \& Weaver, 1989; Dunny, 1990) and Lactococcus (reviewed by Gasson, 1990).

Donor strains of $E$. faecalis are induced by small peptides (the so-called sex pheromones), secreted by putative recipient strains, to produce new surface proteins which form an aggregation substance that mediates the visible autoaggregation ('clumping') of the donor cells, or their coaggregation with the recipient strain. Aggregation reactions also require a binding substance, present on the outermost envelopes of both the donor and the recipient, which was tentatively identified as lipoteichoic acid (LTA) anchored to the cell membrane and protruding outside the murein complex (Ehrenfeld et al., 1986).

In Lactococcus the high frequency of conjugation is the ultimate result of complex, and not yet completely understood events, starting from an intermolecular rearrangement, taking place during matings, in which plasmid or chromosomal DNA is inserted into the 
conjugative lactose plasmid. The resulting transconjugant progeny have an increased donor ability and a constitutive cell aggregation phenotype (Gasson, 1990; van der Lelie et al., 1991).

Thus, in Gram-positive bacteria, high-frequency conjugation and cell aggregation are closely associated phenotypes. Auto- and coaggregating lactobacilli have been described (Wadstrom et al., 1987; Reid et al., 1988; Reniero et al., 1990) but no information is available on the conjugation efficiences of these strains. This report shows that an autoaggregating $L b$. plantarum strain was able to act as a donor or recipient to pAM $\beta 1$, with a high efficiency of plasmid transfer, when mated on solid surfaces, and at a low rate when conjugations took place in broth. Our results suggest that cell aggregation and high frequency of conjugation are associated with a secreted protein of $32 \mathrm{kDa}$, which recognizes, and specifically binds to, kojibiose [O- $\alpha$-D-glucopyranosyl(1,2)-D-glucose] substitutions on LTAs or teichoic acids (TAs).

\section{Methods}

Bacterial strains and cultural conditions. Autoaggregating Lb. plantarum $4 \mathrm{~B} 2$ and $L b$. casei $5 \mathrm{WR}$ were isolated by the authors from the faeces of human newborns, and then classified and maintained in the Bacterial Collection of the Istituto di Microbiologia UCSC, Piacenza, following routine procedures. Other strains used in conjugation experiments were the previously described $L b$. reuteri DSM 20016 and its pAM $\beta 1$-carrying derivative (Vescovo et al., 1983), $L$ b. plantarum NCFB 1988 (isolated as C106; characters relevant for this study were described by Adams et al., 1969; Archibald et al., 1969; Knox \& Wicken, 1973; Sharpe et al., 1973), Lb plantarum NCFB 343 and $L b$. acidophilus ATCC 4356. The lactose-negative, pAM $\beta 1$-containing $L c$. lactis subsp. lactis SH4174 (Gasson \& Davies, 1980), the erythromycinsensitive, spectinomycin-resistant Lc. lactis subsp. lactis SH4160 (Gasson \& Davies, 1980; Cocconcelli et al., 1985) and the plasmid-free E. faecalis $\mathrm{JH} 2-2$ were also used.

Lactobacilli were grown in MRS (Oxoid) broth or agar, while enterococci were propagated on Brain Heart Infusion (Oxoid); the incubation temperature for both was $37^{\circ} \mathrm{C}$. Anaerobic conditions provided by the Gas Pack System (BBL) were used when required. Lactococci were cultivated on glucose M1 7 (Terzaghi \& Sandine, 1975) at $30^{\circ} \mathrm{C}$.

Isolation of the aggregation-promoting factor. The aggregationpromoting factor (APF) was isolated from culture supernatants of $L b$. plantarum 4B2 using a modification of the method of Tang et al. (1989). Briefly, a $100 \mathrm{ml}$ overnight culture of $L b$. plantarum 4B2 was centrifuged at $3000 \mathrm{~g}$ for $15 \mathrm{~min}$ and the supernatant filtered through a $0.45 \mu \mathrm{m}$ membrane filter. A concentration step was then performed by dialysis at room temperature for $4 \mathrm{~h}$ through a semipermeable membrane tubing, with a $12000 M_{\mathrm{r}}$ cut-off, against polyethylene glycol $\left(M_{\mathrm{r}} 20000\right)$. The concentrated preparation was then precipitated with ammonium sulphate at $70 \%$ saturation, resuspended in $5 \mathrm{mM}-\mathrm{Tris} / \mathrm{HCl}$ buffer $\mathrm{pH} 6.5$, dialysed against the same buffer and reprecipitated with ammonium sulphate at $50 \%$ saturation. A further dialysis against
$10 \mathrm{~mm}$-Tris/HCl buffer $\mathrm{pH} 7$ was performed as a desalting step. These preparations were analysed by SDS-PAGE according to Laemmli (1970).

Recovery and purification of active APF molecules were achieved by electroendosmosis preparative electrophoresis (EPE) (Curioni et al., 1988, 1989). The electroendosmotic preparative electrophoresis unit ELFE (Genofit, Grand-Lancy, Switzerland) was connected to a detector (model 440; Waters) set at $280 \mathrm{~nm}$ and a fraction collector (FC 203; Gilson). The method of Laemmli (1970) was used for the preparation of both the running gel $(\mathrm{T}=12 \%)$ and the stacking gel ( $T=4 \%$ ) for the ELFE unit. The sample was loaded on the top of the stacking gel and the fraction collector device was set to obtain one fraction every 10 drops $(0 \cdot 19-0 \cdot 20 \mathrm{ml})$. The pooled fractions were then dialysed against $10 \mathrm{~mm}$-potassium phosphate buffer pH 5.8 with several changes for at least 10 hours at $4{ }^{\circ} \mathrm{C}$, to remove SDS. Protein concentration was determined by means of BCA Protein Assay Reagent (Pierce)

Aggregation tests. Overnight cultures of appropriate strains were washed with distilled water at least three times, resuspended in the same initial volume of one-quarter-strength $(\mathrm{N} / 4)$ Ringer solution and incubated at room temperature in the presence of at least $1 \%(v / v)$ of freshly prepared sterile culture supernatant or 2-5 $\mu \mathrm{g} \mathrm{APF} \mathrm{ml}^{-1}$. Aggregation was scored positive when clearly visible sand-like particles, formed by the aggregated cells, gravitated to the bottom of the tubes, leaving a clear supernatant, within $2 \mathrm{~h}$.

The role of LTAs in cell aggregation (Ehrenfeld et al., 1986) was evaluated by adding to the aggregation tubes variable amounts of commercially available LTAs (Sigma) isolated from Streptococcus mutans, E. faecalis, Bacillus subtilis and Staphylococcus aureus.

To test for a possible pheromone-like aggregation induction effect, $1-10 \%(\mathrm{v} / \mathrm{v})$ of sterilized culture supernatant or $2-5 \mu \mathrm{g} \mathrm{APF} \mathrm{ml^{-1 }}$ was added to the water-washed cells and left in contact for periods from $10 \mathrm{~min}$ to $3 \mathrm{~h}$. Cells were then washed again in order to remove the added APF and finally resuspended in N/4 Ringer solution to score the aggregation reaction.

Mating experiments. Procedures outlined by Morelli et al. (1988) were followed. In brief, mating mixtures were prepared by using equal amounts, of overnight donor and recipient cells, as inferred by optical density values. A $0.2 \mathrm{ml}$ portion of each mixture was spread on a modified MRS agar medium, free of sodium acetate and adjusted to $\mathrm{pH} \mathrm{7.4}$, and incubated at $37^{\circ} \mathrm{C}$ in anaerobic conditions for $24 \mathrm{~h}$. For broth matings the mixture was diluted 10-fold in the modified MRS broth and then incubated anaerobically at $37^{\circ} \mathrm{C}$ for $24 \mathrm{~h}$. In another set of mating experiments $1-10 \%(\mathrm{v} / \mathrm{v})$ of filter-sterilized $L b$. plantarum 4B2 supernatant or 5-10 $\mu \mathrm{g} \mathrm{APF} \mathrm{ml}^{-1}$ was added to mating mixtures before plating. At the end of the incubation period, the agar-plated cells were collected in $1 \mathrm{ml}$ one-quarter-strength (N/4) Ringer solution, while for broth matings, cells were collected by centrifugation and resuspended in $1 \mathrm{ml}$ of the same Ringer solution. Dilutions were then plated to select donors, recipients and drug-resistant putative transconjugants, using phenotypes already described (Gasson \& Davies, 1980; Vescovo et al., 1983). Lactobacilli were enumerated on Rogosa selective medium (Oxoid), while enterococci were selected on Slanetz \& Bartley medium (Oxoid) and lactococci on glucose M17 (GM17). Erythromycin was added, when required, at a concentration of $50 \mu \mathrm{g}$ $\mathrm{ml}^{-1}$. To test for the presence of a possible pheromone-like mating substance, cells were treated as described in the aggregation test and then spread on mating plates.

Identification of the putative transconjugants. Colonies of the drugresistant putative transconjugants obtained during the different matings were randomly selected for further characterization. Plasmid profiles were also examined using the alkaline lysis method and gel conditions routinely used in our laboratory (Vescovo et al., 1983). 


\section{Results}

\section{Isolation of the aggregation-promoting factor}

Among all the strains studied, only $L b$. plantarum 4B2 showed a strong autoaggregating phenotype. However, after centrifugation and several washings of the cells with distilled water, the autoaggregation properties were lost and the cells remained evenly dispersed when resuspended in Ringer solution. The observation that the addition of $1-10 \%(\mathrm{v} / \mathrm{v})$ of freshly prepared filtersterilized supernatant restored the aggregated phenotype prompted us to investigate the factor(s), present in the supernatant, which were able to promote cell aggregation (Fig. 1).

Filtered supernatant of $L b$. plantarum 4B2 lost its aggregation-promoting ability when incubated with Pronase $\mathrm{E}$ or Proteinase $\mathrm{K}$ (both $1 \mathrm{mg} \mathrm{m} \mathrm{ml}^{-1}$ final concentration for $30 \mathrm{~min}$ at $37^{\circ} \mathrm{C}$ ), suggesting that APF is a protein or polypeptide. To identify and isolate this substance, supernatants of $\mathrm{Lb}$. plantarum 4B2 were concentrated by ammonium sulphate precipitation and dialysed as described in Methods. These preparations retained aggregation-promoting ability. SDS-PAGE of the material revealed two distinct bands with apparent molecular masses of $32 \mathrm{kDa}$ and $29 \mathrm{kDa}$ (Fig. 2). These two proteinaceous bands were separated by means of an EPE system, and the results shown in Fig. 3 demonstrated that it was possible to recover fractions containing pure forms of the two proteins. These samples were dialysed to remove SDS and then tested for their aggregation-promoting properties; only the $32 \mathrm{kDa}$ protein was able to promote aggregation of waterwashed cells of $L b$. plantarum 4B2, Lb. reuteri DSM 20016, Lb. plantarum NCFB 1988 and E. faecalis JH2-2.

\section{Aggregation properties}

The addition of filtered $L b$. plantarum supernatant or APF to cultures of $L b$. reuteri DSM 20016, Lb. plantarum NCFB 1988 and $E$. faecalis $\mathrm{JH} 2-2$ led to a clear aggregation reaction. Lactococci showed a weak aggregation when $10 \%(\mathrm{v} / \mathrm{v})$ of supernatant was added, while $L b$. casei $5 \mathrm{WR}, L b$. acidophilus ATCC 4356 and $L b$. plantarum NCFB 343 did not aggregate when filtered supernatant or APF was added. The presence of $\mathrm{pAM} \beta 1$ did not influence the aggregation reactions.

Induction tests, in which the supernatant or the APF were removed from the cell suspension after variable contact times led to the conclusion that the presence of these substances was necessary for aggregation to occur. APF was thus unable to promote the formation of new aggregation substance(s), but was itself the clumping agent.

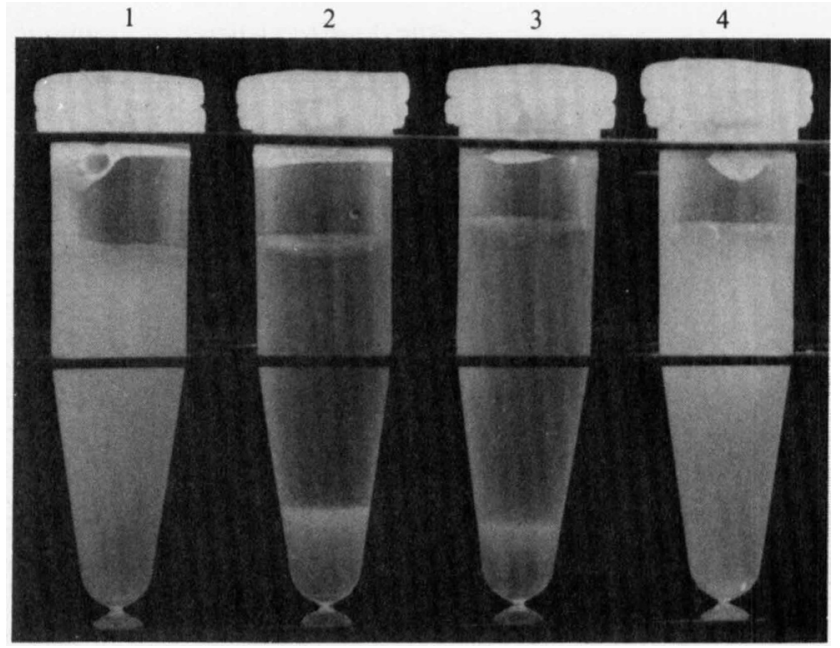

Fig. 1. Aggregation tests with $L$ b. plantarum 4B2. In tube 1, cells were washed three times with water and resuspended in one-quarterstrength Ringer solution. In tube 2 , cells treated as in (1) were added to their own filter-sterilized supernatant. In tube (3) B. subtilis LTAs $\left(1 \mathrm{mg} \mathrm{m} \mathrm{m}^{-1}\right)$ were added to cells treated as in (2). In tube $4, E$. faecalis LTAs $\left(50 \mu \mathrm{g} \mathrm{ml}^{-1}\right)$ were added to cells treated as in (2).

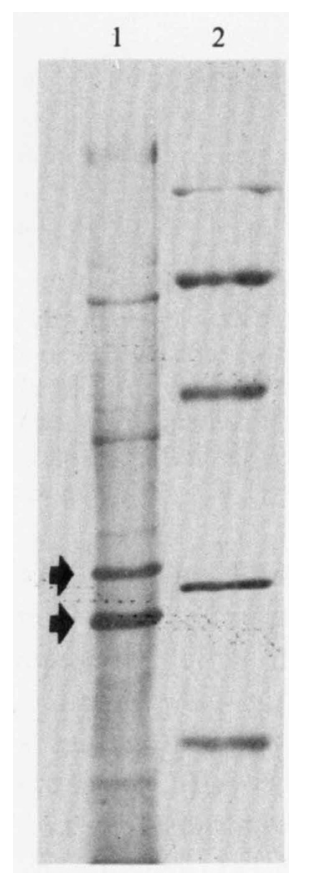

Fig. 2. SDS-PAGE of proteins present in $L b$. plantarum 4B2 culture supernatants. Lane 1, partially purified preparation; arrows indicate the $32 \mathrm{kDa}$ and $29 \mathrm{kDa}$ proteins. Lane 2 , molecular mass markers (rabbit muscle phosphorylase $b, 97.4 \mathrm{kDa}$; bovine serum albumin, $66.2 \mathrm{kDa}$; ovalbumin, $42.7 \mathrm{kDa}$; bovine carbonic anhydrase, $31 \mathrm{kDa}$; soybean trypsin inhibitor, $21.5 \mathrm{kDa}$. Separating gel, $\mathrm{T}=12 \%$; stacking gel, $\mathrm{T}=3 \%$. 
Table 1. Frequencies of conjugal transfer using solid-surface or broth matings

\begin{tabular}{|c|c|c|c|c|}
\hline \multirow[b]{2}{*}{ Donor } & \multirow[b]{2}{*}{ Recipient } & \multicolumn{3}{|c|}{ Frequency* using } \\
\hline & & Solid mating & Broth & h mating \\
\hline \multirow{2}{*}{$\begin{array}{l}\text { Lc. lactis subsp. lactis } \\
\text { SH } 4174(\mathrm{pAM} \beta 1)\end{array}$} & Lb. plantarum 4B2 & $1.0 \times 10^{-2}$ & $3 \cdot 0$ & $\times 10^{-7}$ \\
\hline & $\begin{array}{l}\text { Lb. casei SWR } \\
\text { Lb. reuteri DSM } 20016 \\
\text { Lb. plantarum NCFB } 343 \\
\text { Lb. plantarum NCFB } 1988 \\
\text { Lb. acidophilus ATCC } 4356\end{array}$ & $\begin{array}{l}1.5 \times 10^{-7} \\
5 \cdot 1 \times 10^{-6} \\
2.2 \times 10^{-6} \\
8.5 \times 10^{-7} \\
2.0 \times 10^{-8}\end{array}$ & & $\begin{array}{l}\text { ND } \\
\text { ND } \\
\text { ND } \\
\text { ND } \\
\text { ND }\end{array}$ \\
\hline Lb. reuteri DSM $20016(\mathrm{pAM} \beta 1)$ & $\begin{array}{l}\text { Lc. lactis subsp. lactis SH } 4160 \\
\text { Lb. plantarum 4B2 } \\
\text { Lb. plantarum NCFB } 343 \\
\text { Lb. plantarum NCFB } 1988 \\
\text { E. faecalis JH2-2 }\end{array}$ & $\begin{array}{l}3.9 \times 10^{-7} \\
3.0 \times 10^{-2} \\
2.0 \times 10^{-6} \\
3.2 \times 10^{-7} \\
8.2 \times 10^{-6}\end{array}$ & 5.0 & $\begin{array}{l}\text { ND } \\
\times 10^{-7} \\
\text { ND } \\
\text { ND } \\
\text { ND }\end{array}$ \\
\hline Lb. plantarum 4B2 (pAM $\beta 1)$ & $\begin{array}{l}\text { Lc. lactis subsp. lactis SH } 4160 \\
\text { Lb. reuteri DSM } 20016 \\
\text { E. faecalis JH2-2 } \\
\text { Lb. plantarum NCFB } 343 \\
\text { Lb. plantarum NCFB } 1988\end{array}$ & $\begin{array}{l}3.0 \times 10^{-5} \\
5.0 \times 10^{-2} \\
4.2 \times 10^{-3} \\
8.3 \times 10^{-6} \\
1.2 \times 10^{-2}\end{array}$ & $\begin{array}{l}1 \cdot 2 \\
8 \cdot 1 \\
7 \cdot 2\end{array}$ & $\begin{array}{l}\text { ND } \\
\times 10^{-7} \\
\times 10^{-7} \\
\text { ND } \\
\times 10^{-5}\end{array}$ \\
\hline
\end{tabular}

* Mean frequencies expressed as transconjugants per donor, of at least five different experiments. ND, Not detected.

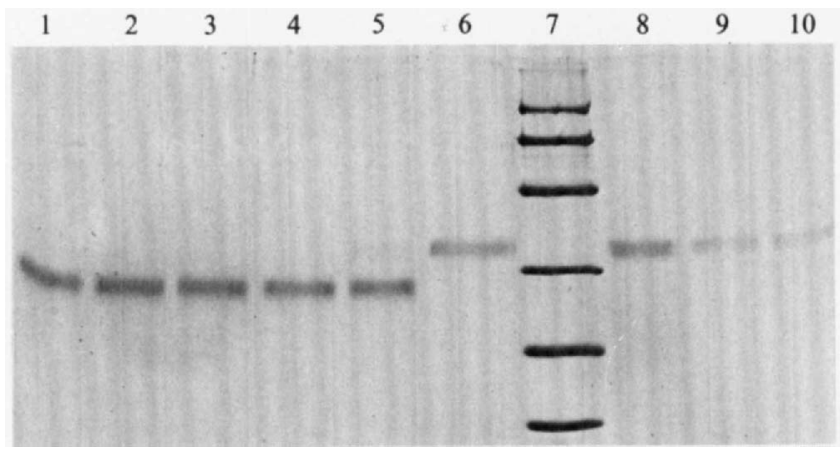

Fig. 3. Purification and separation by EPE (see Methods) of the two major proteins present in $\mathrm{Lb}$. plantarum $4 \mathrm{~B} 2$ supernatant. In lanes 1-4 the $29 \mathrm{kDa}$ protein recovered using EPE is shown, while lanes 6, 8, 9 and 10 demonstrate the recovery of the $32 \mathrm{kDa}$ protein. Lane 5 shows the original preparation containing the two bands. Lane 7 contains molecular mass markers (as in Fig. 2, plus hen egg white lysozyme, $14.4 \mathrm{kDa}$ ). Separating gel, $\mathrm{T}=15 \%$; stacking gel, $\mathrm{T}=3 \%$.

To test the possible role of LTAs in cell aggregation, we added variable amounts of commercially available LTAs to tubes in which aggregation reactions were tested. When $50 \mu \mathrm{g} \mathrm{ml}^{-1}$ (final concentration) of $E$. faecalis LTA was added, together with the sterile spent supernatant or the APF, clumping of cells was not detected in $L b$. plantarum 4B2, Lb. reuteri DSM 20016, $L b$. plantarum NCFB 1988 or E. faecalis JH2-2; in contrast $1 \mathrm{mg} \mathrm{ml}^{-1}$ of the three other LTAs did not affect the aggregation properties in these strains (see Fig. 1).

\section{Mating experiments}

Table 1 summarizes mating experiments performed on solid surfaces or in broth cultures. Frequencies higher than those generally reported were obtained when $L b$. plantarum 4B2 was the recipient, whatever the donor used. Transfer of pAM $\beta 1$ was also obtained in the liquid matings, but at low frequencies.

When one $L b$. plantarum 4B2 transconjugant was used as the $\mathrm{pAM} \beta 1$ donor, high-frequency conjugal transfer was obtained only when recipients sensitive to the APF were used.

The addition of filtered $L b$, plantarum 4B2 supernatants or the APF to the aggregation-sensitive strains increased the efficiency of conjugation (Table 2).

Induction tests did not influence the frequency of conjugation (data not shown).

Table 2. Frequencies of plasmid transfer in solid-surface matings in the presence of filtered $L b$. plantarum $4 B 2$ supernatants or $A P F$

\begin{tabular}{cccc}
\hline \hline & & \multicolumn{2}{c}{ Frequency* with } \\
\cline { 2 - 4 } Donor & Recipient & Supernatant & APF \\
\hline $\begin{array}{c}\text { Lc. lactis subsp. lactis } \\
\text { SH 4174 (pAM } \beta 1 \text { ) }\end{array}$ & $\begin{array}{c}\text { Lb. reuteri } \\
\text { DSM 20016 }\end{array}$ & $4.1 \times 10^{-4}$ & $5.0 \times 10^{-2}$ \\
& $\begin{array}{c}\text { Lb. plantarum } \\
\text { NCFB 1988 }\end{array}$ & $5.0 \times 10^{-3}$ & $4.2 \times 10^{-2}$ \\
Lb. reuteri DSM & $\begin{array}{c}\text { E. faecalis } \\
\text { JH2-2 }\end{array}$ & $2.1 \times 10^{-3}$ & $3.0 \times 10^{-2}$ \\
Lbo16 (pAM $\beta 1)$ & $\begin{array}{c}\text { Lb. plantarum } \\
\text { NCFB 1988 }\end{array}$ & $2.0 \times 10^{-4}$ & $4.2 \times 10^{-3}$ \\
\hline \hline
\end{tabular}

* Mean frequencies, expressed as transconjugants per donor, of at least five different experiments. Culture supernatant was added at $10 \%$

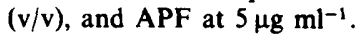




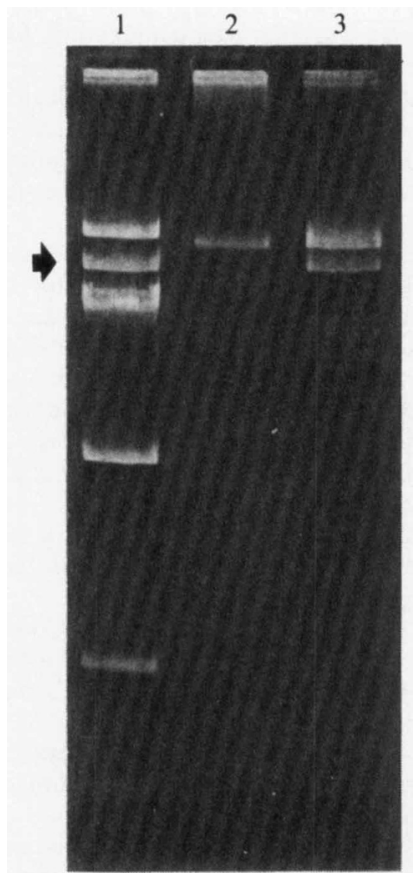

Fig. 4. Agarose gel electrophoresis of plasmid profiles. Lane 1, $L c$. lactis subsp. lactis SH 4174 (pAM $\beta 1$ donor). Lane 2, Lb. plantarum 4B2 (containing one native plasmid). Lane 3 , a $L b$. plantarum 4B2 transconjugant containing $\mathrm{pAM} \beta 1$. Arrow indicates $\mathrm{pAM} \beta 1$.

\section{Identification of the putative transconjugants}

The presence of $\mathrm{pAM} \beta 1$ in randomly selected EryR transconjugants was confirmed by isolation of plasmid DNA and visualization on agarose gel electrophoresis (Fig. 4).

\section{Discussion}

In this study we have shown that high-frequency pAM $\beta 1$ conjugal transfer can be obtained in lactobacilli. Among Gram-positive bacteria only some strains of enterococci and lactococci are able to transfer plasmid DNA at a high rate; in both organisms this capacity is linked to the appearance of a 'clumping' phenotype (reviewed by Clewell \& Weaver, 1989; Gasson, 1990), which causes the aggregation of donor and recipient cells. These observations prompted us to investigate the effect on pAM $\beta 1$ conjugal transfer efficiency when autoaggregating bacteria were used.

A preliminary screening allowed us to select $L b$. plantarum 4B2 for study. Its coaggregation capacity was lost when cells were washed and resuspended in water, but could be restored by adding its own supernatant. The proteinaceous nature of the APF was then determined and the substance was isolated and shown to be a $32 \mathrm{kDa}$ protein. This protein, as well as the filter-sterilized supernatant, was able to induce aggregation not only in the producer strain, but also in some strains of $E$. faecalis, $L b$. reuteri, $L b$. plantarum and, to a lesser extent, $L c$. lactis. The APF was not active on $L b$. casei, $L b$. acidophilus and another strain of $L b$. plantarum. These results suggest that a specific binding substance present on the outermost envelopes of positively reacting strains is required for aggregation to occur.

The nature of the receptor for the aggregating protein is indicated by comparison of the composition of the cell walls of the aggregating and non-aggregating strains. $L b$. plantarum NCFB 1988 lacks the precipitinogen-specific group of Lb. plantarum (Adams et al., 1969), which is a glucosylribitol TA (Sharpe et al., 1973). Instead, walls of this strain contain a glycerol TA, with glucosyl substituents attached to the primary hydroxyl group of glycerol (Adams et al., 1969). Moreover, these substituents occur as kojibiose [O- $\alpha$-D-glucopyranosyl-(1,2)-D-glucose], a complex sugar characterized by the formation of a 'pocket' in its structure (Knox \& Wicken, 1973). The observation that $E$. faecalis LTAs also have the same substituents (Knox \& Wicken, 1973), supports the identification of the receptor as kojibiose-containing LTAs. Lc. lactis strains also have $\alpha$-1,2-diglucosyl substituents on their LTAs, but only as terminal components. No information is available, to our knowledge, on the LTA composition of $L b$. reuteri strains; $L b$. case $i$ strains do not have glucosylated LTAs, while LTAs of $L b$. acidophilus strains do not contain the $\alpha-1,2$ linkage in their glycosyl substituents (Wicken, 1980). Inhibition of aggregation reactions was obtained only when $E$. faecalis LTAs were used, confirming the identification of the binding substance.

This report shows that the presence of an aggregation phenotype in Lactobacillus is mediated by a protein able to establish a bridge between two bacterial cells containing, as binding substance, the kojibiose-substituted LTAs or TAs. Coaggregated bacteria are able to transfer plasmid DNA at a very high rate when matings occur on solid surfaces, and at a low frequency in broth mating. No induction reaction resembling those described for the sex pherormone of $E$. faecalis was ever detected.

The highest conjugation frequencies were detected when $L b$. plantarum strain $4 \mathrm{~B} 2$ was used as recipient; a possible explanation of this might be that intra-recipient conjugal transfer took place during the mating, in which the first transconjugants acted as donors during the subsequent rounds of cell replication.

The aggregation mechanism described here strongly resembles the protein-mediated adhesion of a $L b$. fermentum strain to mouse stomach squamous epithelium described by Conway \& Kjelleberg (1989). Moreover, $L b$. acidophilus $\mathrm{ADH}$, the only Lactobacillus strain for which 
high-frequency plasmid transfer, by agar matings, has been reported, is able to adhere to intestinal tissue (Luchansky et al., 1989).

The observation that secreted proteins in Lactobacillus can play a central role in a number of relevant phenotypes clearly encourages further research in this area.

We gratefully acknowledge Dr H. J. Gilbert for his help in revising the manuscript.

\section{References}

Adams, J. B., Archibald, A. R., Baddiley, J., Coapes, H. E. \& DAvison, L. (1969). Teichoic acids possessing phosphate-sugar linkages in strains of Lactobacillus plantarum. Biochemical Journal 113, 191-193.

Archibald, A. R., Coapes, H. E. \& Stafford, G. H. (1969). The action of dilute alkali on bacterial cell walls. Biochemical Journal 113 , 899-900.

Clewell, D. B. \& Weaver, K. E. (1989). Sex pheromones and plasmid transfer in Enterococcus faecalis. Plasmid 21, 175-184.

Clewell, D. B., YaGi, Y., DunNy, G. M. \& Schultz, S. K. (1974) Characterization of three deoxyribonucleic acid molecules in a strain of Streptococcus faecalis: identification of a plasmid determining erythromycin resistance. Journal of Bacteriology 117, 283-289.

Cocconcelli, P. S., Morelli, L. \& Vescovo, M. (1985). Conjugal transfer of antibiotic resistances from Lactobacillus to Streptococcus lactis. Microbiologie-Aliments-Nutrition 3, 163-165.

Conway, P. L. \& KJELLeberg, S. (1989). Protein-mediated adhesion of Lactobacillus fermentum strain 737 to mouse stomach squamous epithelium. Journal of General Microbiology 135, 1175-1186.

Curioni, A., Dal Belin Peruffo, A. \& Nuti, M. P. (1988). Purification of cellulases from Streptomyces A20 by electroendosmotic preparative electrophoresis. Electrophoresis 9, 327-330.

Curioni, A., Dal Belin Peruffo, A. \& Pogna, N. E. (1989) Electroendosmotic preparative electrophoresis as a one-step method for purification of high molecular weight subunits of wheat glutenin. Cereal Chemistry 66, 133-135.

DuNNY, G. M. (1990). Genetic functions and cell-cell interactions in the pheromone-inducible plasmid transfer system of Enterococcus faecalis. Molecular Microbiology 4, 689-696.

Ehrenfeld, E. E., Kessler, R. E. \& Clewell, D. B. (1986) Identification of pheromone-induced surface proteins in Streptococcus faecalis and evidence of a role for lipoteichoic acid in formation of mating aggregates. Journal of Bacteriology 168, 6-12.

FitzGerald, G. F. \& GASSON, M. J. (1988). In vivo transfer systems and transposons. Biochimie 70, 489-502.

Gasson, M. J. (1990). In vivo genetic systems in lactic acid bacteria FEMS Microbiology Reviews 87, 43-60.

Gasson, M. J. \& Davies, F. L. (1980). Conjugal transfer of the drug resistance plasmid pAM $\beta 1$ in the lactic streptococci. FEMS Microbiology Letters 7, 51-53.

Gibson, E. M., Chace, N. M., London, S. B. \& London, J. (1979). Transfer of plasmid mediated antibiotic resistance from streptococci to lactobacilli. Journal of Bacteriology 137, 614-619.

IWATA, M. (1989). Characterization of a pAM $\beta 1$ deletion derivative isolated from Lactobacillus casei after conjugation. Biochimie 70, 553558.

KNOX, K. W. \& WICKEN, A. J. (1973). Immunological properties of teichoic acids. Bacteriological Reviews 37, 215-257.

LAEMmLi, U. K. (1970). Cleavage of structural proteins during the assembly of the head of bacteriophage T4. Nature, London 227, 680685.

van der Lelie, D., Chavarri, F., Venema, G. \& Gasson, M. J. (1991) Identification of a new genetic determinant for cell aggregation associated with lactose plasmid transfer in Lactoccoccus lactis. Applied and Environmental Microbiology 57, 201-206.

Luchansky, J. B., Kleeman, E. G., Raya, R. R. \& KlaEnhammer, T R. (1989). Genetic transfer systems for delivery of plasmid deoxyribonucleic acid to Lactobacillus acidophilus ADH: conjugation, electroporation, and transduction. Journal of Dairy Science $\mathbf{7 2}$, 1408-1417.

Morelli, L., Sarra, P. G. \& Bottazzi, V. (1988). In vivo transfer of pAM $\beta 1$ from Lactobacillus reuteri to Enterococcus faecalis. Journal of Applied Bacteriology 65, 371-375.

Reid, G., McGroarty, A. J., Angotti, R. \& CoOK, R. L. (1988), Lactobacillus inhibitor production against Escherichia coli and coaggregation ability with uropathogens. Canadian Journal of Microbiology 34, 344-351.

Reniero, R., Morelli, L., Callegari, M. L., Sommi, P. \& Bottazzi, V. (1990). Surface proteins in enteric lactobacilli. Annali di Microbiologia ed Enzimologia 40, 83-91.

ROMERo, D. A. \& MCKAY, L. L. (1985). Isolation and plasmid characterization of a Lactobacillus species in the manufacture of fermented sausage. Journal of Food Protection 48, 1028-1035.

Sharpe, N. E., Brock, J. H., Knox, K. W. \& Wicken, A. J. (1973). Glycerol teichoic acid as a common antigenic factor in lactobacilli and some other Gram-positive organisms. Journal of General Microbiology 74, 119-126.

Shrago, A. W., Chassy, B. M. \& Dobrogosz, W. J. (1986). Conjugal plasmid transfer (pAM $\beta 1)$ in Lactobacillus plantarum. Applied and Environmental Microbiology 52, 574-576.

Tang, M., Owens, K., Pietri, R., Xiarung, Z., McWeigh, R. \& Gosh, B. K. (1989). Cloning of the crystalline cell wall protein gene of Bacillus licheniformis NM105. Journal of Bacteriology 171, 66376648 .

TANNOCK, G. W. (1987). Conjugal transfer of plasmid pAM $\beta 1$ in Lactobacillus reuteri and between lactobacilli and Enterococcus faecalis. Applied and Environmental Microbiology 53, 2693-2695.

TERZAGHI, B. E. \& SANDINE, W. E. (1975). Improved medium for lactic streptococci and their bacteriophages. Applied Microbiology 29, 807813.

Vescovo, M., Morelli, L., Bottazzi, V. \& Gasson, M. J. (1983). Conjugal transfer of broad host range plasmid pAM $\beta 1$ into enteric species of lactic acid bacteria. Applied and Environmental Microbiology 46, 753-755.

W ADSTrom, T., ANDERSSON, K., Sydow, M., AXELSSON, L., LindGREN, L. \& Gullam, B. (1987). Surface properties of lactobacilli isolated from the small intestine of pigs. Journal of Applied Bacteriology 62 , 513-520.

West, C. A. \& WARNER, P. S. (1985). Plasmid profiles and transfer of plasmid encoded antibiotic resistance in Lactobacillus plantarum. Applied and Environmental Microbiology 50, 1319-1321.

WICKEN, A. J. (1980). Structure and cell membrane-binding properties of bacterial lipoteichoic acids and their possible role in adhesion of streptococci to eukaryotic cells. In Bacterial Adherence, pp. 137-158. Edited by E. A. Beachey. London \& New York: Chapman \& Hall. 